\title{
多光子励起過程による行動・運動を司る神経細胞ネットワーク活動の イメージングと光操作
}

\author{
松崎 政紀 ${ }^{1,2}$, 平 理一郎 ${ }^{1,2}$, 大久保 文貴 ${ }^{1,2}$ \\ 1総合研究大学院大学 自然科学研究機構基礎生物学研究所光脳回路研究部門 ( $4444-8585$ 愛知県岡崎市明大寺町字西郷中 38 ) \\ ${ }^{2}$ JST CREST ( ₹332-0012 埼玉県川口市本町4-1-8)
}

\section{Two-Photon Imaging and Photomanipulation of Multicellular Neural Activity in Awake Behaving Animals}

\author{
Masanori MATSUZAKI, Riichiro HIRA, and Fuki OHKUBO \\ ${ }^{1}$ Division of Brain Circuits, National Institute for Basic Biology and the Graduate University of Advanced Studies (Sokendai) \\ Myodaiji, Okazaki, Aichi 444-8585 \\ ${ }^{2}$ Japan Science and Technology Agency, CREST, 4-1-8 Honmachi, Kawaguchi, Saitama, 332-0012
}

(Received October 1, 2012)

\begin{abstract}
Two-photon imaging is a powerful tool used to examine molecular and cellular functions in living tissues. In particular, calcium imaging can quantitatively measure neuronal activity i.e. action potential firing. Two-photon calcium imaging can detect the multicellular activity of neuronal circuits in the brain at the single cell level while animals perform behavioral tasks. Normal two-photon microscopy can be applied to head-restrained mice, while fiber-optic, head-mounted miniaturized two-photon microscopes can be used in unrestrained mice. Here, we review the general mechanisms and methodologies for twophoton calcium imaging in awake behaving mice. In addition, we also briefly discuss the manipulation of photoactivatable proteins (optogenetics), which can be used to activate or inhibit specific types of neurons and animal behaviors with millisecond precision.
\end{abstract}

Key Words: Two-photon imaging, Calcium-sensitive fluorescent molecule, Awake animal, Optogenetics, Channelrhodopsin-2

\section{1. はじめに}

私たちは，レーザー光路を最適化するためにきちんと した手順に従いミラー調整を行うことができる，日常生 活においても，なにげもなく歯を磨いたり，少し練習す ればスマートフォンを楽々と使いこなしたりできる。こ の時, 脳の中ではどのようなことが起こっているのだろ うか. 本論文では, 小動物 (主にマウス)が様々な行動を 行なっているときの多数の脳神経細胞活動を計測するた めの技術を紹介する。この技術を用いることによって, 外界の環境の変化や内的変化に応じて適切な行動を起こ すための神経回路の動作原理が明らかにされ, 神経・精 神疾患における脳回路動作の異常機構の解明に繋がると 期待される。計測方法として, 生体での分子, 細胞のダ イナミクスを明らかにする上で最も有用な方法論である 2光子イメージングを用いるが，本方法論の詳細につい ては根本氏の稿を参照されたい，細胞機能変化の良い指 標となる細胞内カルシウム濃度变化をカルシウム濃度感 受性蛍光指示薬の蛍光強度変化として2光子イメージン
グによって捉えることで，生きた個体小動物における多 数の神経細胞の発火(活動電位) 活動を単一細胞レベルで 計測することができる，さらに，頭部固定下での行動中 の，または自由行動下での行動中の脳内活動を計測する 2光子イメージング技術も開発され, 神経科学は脳内 ニューラルネットワークをリアルタイムで観察する, と いう局面に突入している。ささに，陽イオンを細胞内外 で透過させる光駆動型タンパク質チャネルロドプシン2 (ChR2) が緑藻クラミドモナスにおいて発見され，これ をコードする遺伝子を神経細胞に導入することで，覚醒 中の動物の神経細胞活動や行動までもがミリ秒単位でリ アルタイムに光操作することが可能となってきた ${ }^{1)}$ 。本 稿ではこれらの現状について, 細胞レベルでの基本的な 説明も含め概説する。

2. In vivo 2光子カルシウムイメージング

細胞内カルシウムイオンは2次メッセンジャーとして 働き, 細胞が機能を発揮するときの多くでその濃度が上 
昇する(数百ナノモルから数十マイクロモル). 従って， 細胞内カルシウム濃度変化を計測することは, 細胞機能 変化を検出する上で大きな指標となる。特に, 神経細胞 の活動は細胞内へのナトリウムイオンの流入による細胞 膜電位の脱分極によって引き起こされる活動電位 (発火) の伝播に規定される，発火時，膜電位感受性カルシウム チャネルも開口し細胞内へカルシウムイオンが流入する ため細胞内カルシウム濃度が上昇する。 そこで, 細胞内 ヘカルシウム濃度感受性蛍光指示薬(Fig. 1) を導入し, これを蛍光イメージングすることで単一の活動電位をカ ルシウム濃度上昇として計測可能である (Fig. 2)。カル シウム濃度感受性蛍光指示薬として, カルシウムキレー ターと蛍光発色団が結合した小分子化合物 (fura-2, Oregon Green 488 BAPTAなど) が広く用いられている (Fig. 1)。神経細胞における活動電位は約 1 ミリ秒の現象 であるが，空間的なカルシウムの拡散とカルシウム結合 タンパク質の結合時定数によって細胞内濃度は数百ミリ 秒の減衰時定数を持って元に戻る。従ってイメージング 速度が数 Hzでも発火現象を捉えることができる. 複数 の発火が起こる場合は, 蛍光量が合算されるため, 蛍光 指示薬とカルシウムの結合が飽和しない限り発火回数も 定量化可能であるが，より高速なイメージングが必要で ある。蛍光小分子化合物は細胞外から内に透過すること ができないため，電極などを用いて細胞内に注入する必 要があるがこのような場合では注入される細胞数が限ら れる。一方でこれらの分子のアセトキシメチルエステル 体(AM体)では細胞外から内に容易に透過することがで き, 細胞内でエステラーゼ活性によってAMが解離する ことでカルシウム指示分子として機能する.このAM体 をガラス管を用いて生きた個体の脳組織内に注入し約 1 時間かけて注入領域の近傍で細胞内に取り込ませること で，数百個以上の多数の神経細胞でのカルシウムイメー ジングが可能となる ${ }^{2)}$. この方法は，ゼブラフィッ シュ，マウス，ラット，フェレット，ネコにも広く適用

Oregon Green 488 BAPTA-1

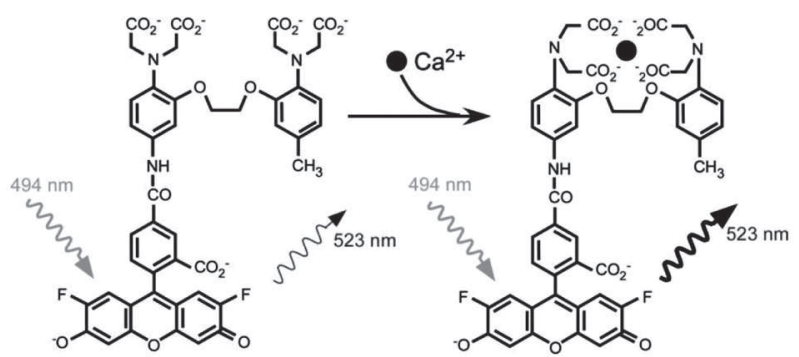

Fig. 1 Calcium-sensitive fluorescent small molecule.

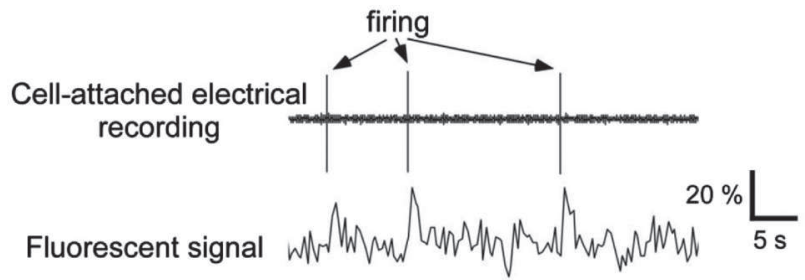

Fig. 2 Calcium transients detected by two-photon imaging of a neuron in vivo.
されている。この方法によって多数の細胞活動の時系列 情報を捉えることが可能となった。例えば麻酔下のマウ スおよびネコの視覚野において，視覚野の上部の頭蓋骨 を開けそこにガラス空を設置し，その上から顕微鏡の対 物レンズを使って2光子イメージングすることで，視覚 刺激に対して方位選択反応性を持つ細胞の分布が単一細 胞レベルで明らかとなった ${ }^{3)}$

上記の蛍光小分子化合物を用いる方法では，実験ごと に化合物を注入する必要がある。この化合物は何日間も 安定して細胞内にとどまることができないため，化合物 を導入した細胞を長期に観察することはできず，また細 胞種特異的に導入することはできない. 1997年に, 緑色 蛍光タンパク質 (GFP) とカルシウム結合タンパク質を融 合したカルシウム濃度感受性蛍光タンパク質が発表され て以来 ${ }^{4)}$, 様々な改変体の開発が行われ，体温38度付近 の個体脳においても十分な蛍光変化量を持つタンパク質 が報告されている(Camaleon, GCaMPなど ${ }^{5,6)}$ 。例えば Fig. 3のGCaMPでは，カルシウム結合タンパク質である カルモジュリンと, カルシウム結合カルモジュリンに結 合するM13ペプチドが改変型GFPに融合している，細胞 内のカルシウム濃度が上昇すると, カルシウムがカルモ ジュリンに結合し融合タンパク質の構造が大きく変化す ることでGFPの蛍光強度が増大する. タンパク質のアミ ノ酸配列は遺伝子によってコードされているので，この 配列をコードする遺伝子を適切な転写プロモーターにつ なぎ，任意の領野や特異的夕イプの細胞に導入すること で，このタンパク質を標的となる細胞において長期的に 発現させることができる，例えばマウスにおいては，視 覚野，体性感覚野，運動野，頭頂葉，海馬での2光子イ メージングが報告されている。遺伝子導入後は，発現細 胞はそのまま観察し続けることができ, 数週間以上にわ たって同一細胞の活動をイメージングすることも報告さ れている6).

\section{3. 頭部固定覚醒小動物での2光子イメージング法}

通常の顕微鏡で2光子イメージングを行う場合は，顕 微鏡が固定されているため, 対象となる動物の脳も固定 されている必要がある。多くの場合，小動物頭部に固定 具を接着し，これをステージ上にネジなどによって固定 し，開頭部位にガラス空を設置することでイメージング を行う。動物の心拍や体動の影響を完全に除くことは難 しく，当初の実験では体動が少ない麻酔下での観察が主 たるものであった。しかし動物の行動や意思決定がどの ような細胞活動によって成り立っているのか, 疾患での

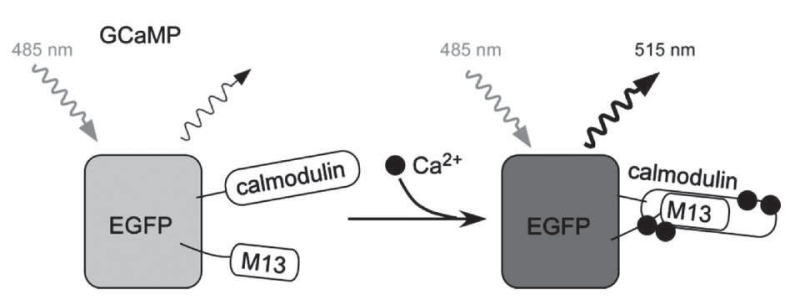

Fig. 3 Calcium-sensitive fluorescent protein. 
行動異常がどのような細胞活動異常に基づくのかを理解 するためには，覚醒動物で実験を行なう必要がある。覚 醒動物においても，頭部固定をより強固にし，加画像 摇れを実験終了後に画像処理することによって，画質の 高い画像を復元できるようになっている(後述，Fig.4). これまでに，二つの異なった匂いを頭部固定のマウスに 嗅がせながら, 片方の匂い時には水を舐め, もう片方の 匂いのときには舐めさせない，という課題を学習させる ことで，それぞれの行動に特異的な細胞群が2光子イ メージングによって同定されている(Fig. 5(A)) 7)。 また ポールの位置をヒゲによってマウスに認知させ, その位 置によって水を舐めるか舐めないかを学習させる課題に おいてもヒゲ運動や水舐め運動に関連した細胞群が同定 された (Fig. $5(\mathrm{~A}))^{8)}$. 特に面白い実験系として, トラッ キングボールにマウスを載せて四肢の動きは自由にさ せ，そのボールの回転を検出しながらそれに合わせてマ ウスの視野内の画面を変化させることでバーチャル空間 内を移動できるというシステムが開発されている (Fig. $5(B))^{9,10)}$. このことによって, バーチャル空間内 を歩き, ある地点に到達すると餌を得られるように学習 させ，ある場所で特異的に反応する海馬の神経細胞を2 光子イメージングによって同定することや ${ }^{10)}$ ，バーチャ ルT字迷路での左右どちらにいくかの意思決定に関わる 神経細胞活動が頭頂葉から計測されている ${ }^{11)}$ 。これらの 実験において，隣接した細胞ほどその活動パターンの相 関が強い傾向があるものの, 異なった感覚刺激に応答す る細胞や異なった時間経過で活動する細胞が局所的(数 百 $\mu \mathrm{m}$ 以内)にも混在していること, 学習によってその活 動パターンが変化することが見出されており，ダイナ

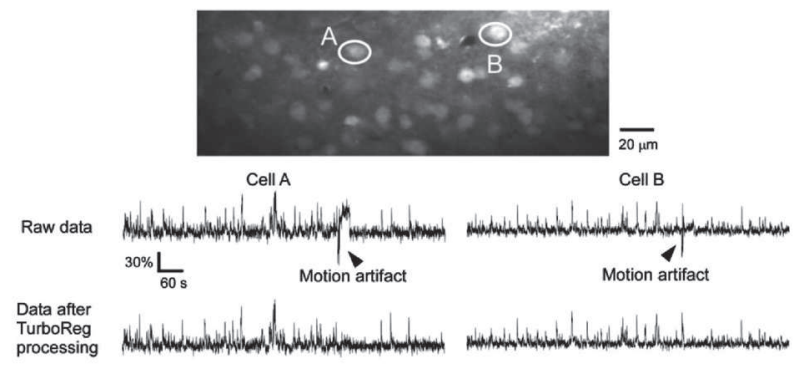

Fig. 4 Two-photon calcium imaging in an awake mouse.

A

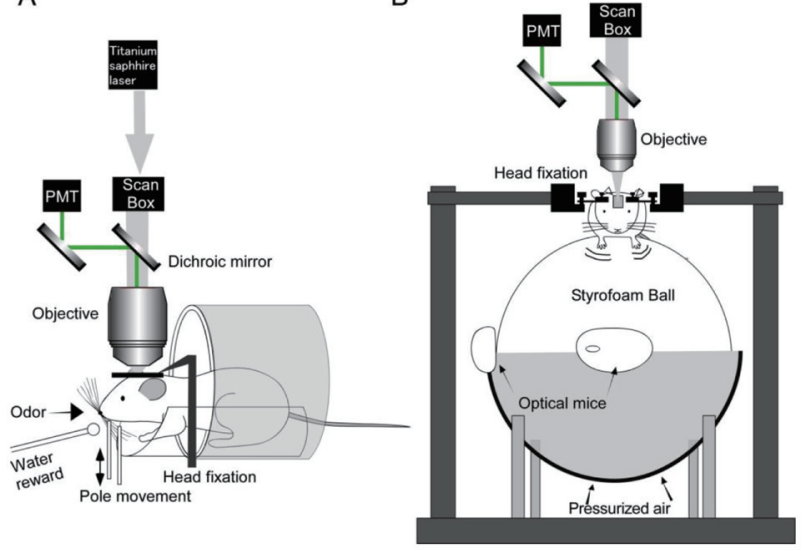

Fig. 5 Two-photon imaging for head-restrained mice.
ミックなネットワークが大脳皮質局所領域において形成 されていることが明らかになりつつある。

\section{4. 自由行動下の覚醒小動物における 2光子イメージング法}

自由行動下の動物での脳活動を計測するためには，動 物を固定された顕微鏡の下に置くことはできない.そこ で，小型走査装置を頭部に固定し光導入にファイバを用 いる，という方法で自由行動下での 2 光子イメージング が試されている (Fig. 6) ${ }^{12,13)}$ ，個体脳での2光子イメージ ングでは, 数十ミリワット, 時には数百ミリワットの レーザー照射が必要となる。高出力のフェムト秒パルス レーザーをファイバで伝送する際に発生する非線形光学 効果を抑制するために，大口径シングルモードファイバ や中空コアフォトニック結晶ファイバが用いられてい る $^{14,15)}$. ファイバ出射後の走査装置はマウスやラットの 頭部に固定するため小型化する必要がある。 そのため レーザー走査方法としては，2枚のガルバノミラーを用 いるものではなく, 例えばファイバ端を小型のピエゾ素 子で共振させることで, 2次元のルサージュ走査や, ら せん走査が実現されている。 これらの走査によって得ら れる蛍光を，再びファイバに導入して遠方のPMTに集 光させるか, 頭蓋骨に設置した小型装置にPMTを設置 することで検出する (Fig. 6). この信号を2次元再構築す ることでXYT画像取得が可能となる。対物レンズとし ては小型の屈折率分布型GRINレンズを用いる方法も開 発されており，現在では頭部固定装置の重量は1グラム 以下が達成されている ${ }^{16)}$ 。この2光子イメージングでは 空間解像度では側方 $0.98 \mu \mathrm{m}$, 光軸方向7.68 $\mu \mathrm{m}$ が達成さ れており, 個体脳での小脳プルキンエ細胞の自発活動や ゆるやかなオシレーション活動が検出された。ファイバ 導入による方法では通常の固定された顕微鏡計測に比べ て, 視野が狭い, 対物レンズのNAが 0.5 程度と空間解像 度が低い, 走査方法の性質上SN比が悪いなどの欠点が あるが, 自然な行動での活動を計測できる点で魅力的で あり，技術面でのさらなる開発が望まれる。

\section{5. 高速イメージング}

生体2光子イメージングの技術的な問題はその速さが
A

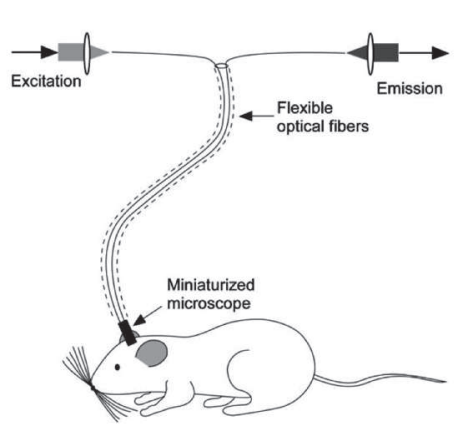

B

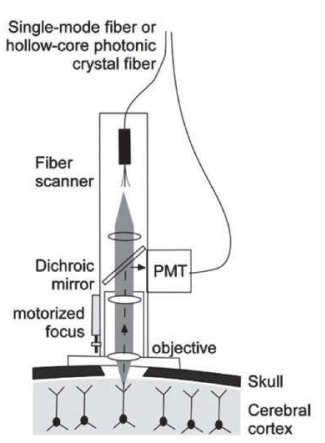

Fig. 6 Two-photon imaging for freely-moving mice. 
神経活動に比べ遅いことである。例えば全視野でイメー ジングすると, 通常のガルバノミラーを用いた2次元走 査では数Hzのフレームレートが限界である (Table 1). そのため, カルシウム蛍光信号を十分な時間解像度で定 量化することが難しい，高速走査法のひとつは走査軸の 片方に共振型スキャナを用いることで，フレームレート を数十Hzまで上げられるが周波数が固定されるという 問題点がある。他にも，レーザービーム分割によって複 数のビームを同時に顕微鏡に導入し複数の光検出器で 個々のスポットからの蛍光を検出する方法や, スピニン グディスク法, 光変調器を用いた走査法がある $(\text { Table } 1)^{13)}$. 大きな可能性としては, 音響光学偏向器 AODによるレーザーの走査がある。直交したふたつの AOD結晶にレーザーを導入し，それぞれの結晶に音波 を伝播させ高速に結晶内の屈折率を変調することで $10 万$ 以上の点群を 1 秒で走査することが可能である ${ }^{17)}$. ピエ ゾ素子を用いて光軸方向に対物レンズを上下させること で高速3次元イメージングが実現化されている ${ }^{18)}$. ピエ ゾ素子の代わりに，AODを追加してレーザーの広がり 角を制御することでも光軸方向の焦点位置の走査が可能 となる ${ }^{19)}$. しかしこのような3次元内での多数の点と点 を結んで走査するランダム走査の場合, 画面摇れ補正に 必要な近傍空間での信号情報が得られないため, 覚醒時 でのイメージングには適さないという久点がある.

\section{6. 画像処理技術}

カルシウムイメージングからどのように多細胞ネット ワークのダイナミクスを抽出するか，という道具立ては まだ個々のラボで開発をしている段階にある。ノイズが なければ原理的には単一の活動電位から検出可能である が, 信号ノイズは, 励起光強度, イメージング速度, 光 検出器の性能, 蛍光分子のカルシウム結合特性, 濃度や 蛍光強度などの因子に依存するため, 実際にはすべての 活動電位を検出することは困難である．特に覚醒下では 運動による画像摇れが重大な画質低下を引き起こしう る。脳が動かないように動物固定装置を頑丈にすること が重要であるが, 焦点平面内での摇れに関しては，隠れ マルコフモデルやLucas-Kanadeアルゴリズムによって画 像がどの方向にどれだけ動いたかをオフラインで推定す る方法によって改善することが報告されている ${ }^{9,20)}$ ．例 えばオープンソースソフトウェアであるImageJ (NIH)の TurboReg ${ }^{21)}$ を用いると，Fig.4にあるように同一平面内 でのmotion artifactを大幅に補正することが可能である.

Table 1 Scanning methods.

\begin{tabular}{ccc}
\hline & Scanning rate (full field) & Random access rate \\
\hline Galvano & $\leq 8 \mathrm{~Hz}$ & $\sim 500 \mathrm{~Hz}$ \\
Resonant & $\leq 40 \mathrm{~Hz}$ & $\times$ \\
Spinning disk & $\sim 100 \mathrm{~Hz}$ & $\times$ \\
AOD & $\sim 100 \mathrm{~Hz}$ & $\sim 100 \mathrm{kHz}$ \\
Piezo & - & $\sim 10 \mathrm{~Hz}$ (z axis) \\
\hline
\end{tabular}

蛍光変化量に基づく細胞発火時系列の多次元行列演算に よって, 細胞活動のペア相関や，主成分分析などによる 集団活動の特徴抽出, 多細胞アンサンブル活動からの行 動予測などが可能となる。蛍光イメージングであるた め，活動細胞の投射先や種類を蛍光ラベリングや抗体染 色によって同定することや, 活動細胞間の相対的空間配 置も定量化することができる.

\section{7. 光遺伝学による光操作}

カルシウムイメージングはある現象に随伴して起こる 細胞活動の変化を計測するものである，すなわち，現象 と計測対象物の相関関係を明らかにする，ということで あって，必ずしも因果関係を示すものではない，後者を 実現するためには，計測された細胞活動がある現象の誘 導に必要十分であることを示す必要がある。そのために は，任意の細胞活動のオンオフ制御を任意の時間で行う ことが要求される。これが光を使ってできるようになっ てきた，というのが最近の神経科学における大きな進展 である ${ }^{22)}$. ChR2は緑藻クラミドモナス由来の古細菌型 ロドプシンであり，7回膜貫通ドメインを持つ膜タンパ ク質で，発色団はレチナールである(Fig. 7 ${ }^{23)}$ 。レチ ナールはChR2タンパク質の7番目のヘリックスに保存さ れているリジン残基とシッフ塩基を形成して共有結合し ており，青色の光子を吸収すると, all-trans型から13-cis 型に変化し(Fig. 7), それがタンパク質の構造変化を引 き起こし，陽イオンが透過する，光照射を止めると ChR2は不活性化状態に遷移し, レチナールは再びalltrans型に変換し静止状態に戻る。これらの遷移時定数は 数ミリ〜10ミリ秒程度である. ChR2はいわば, 細胞活 動を〜 $100 \mathrm{kHz}$ で制御できる内向き整流性フォトダイ オードということになる. ChR2遺伝子を神経細胞に導 入し，これを光照射することで，任意の時間で活動電位 を誘発できる(Fig. 8).ささらに黄色光吸収によって駆動 されるCl-ポンプタンパク質であるハロロドプシン (HR) およびH+ポンプタンパク質であるバクテリオロドプシ ン $(\mathrm{BR})$ の発現によって, 逆向きの制御, すなわち神経 細胞の過分極も可能になった (Fig. 7 $)^{24,25)}$. これらも遺伝

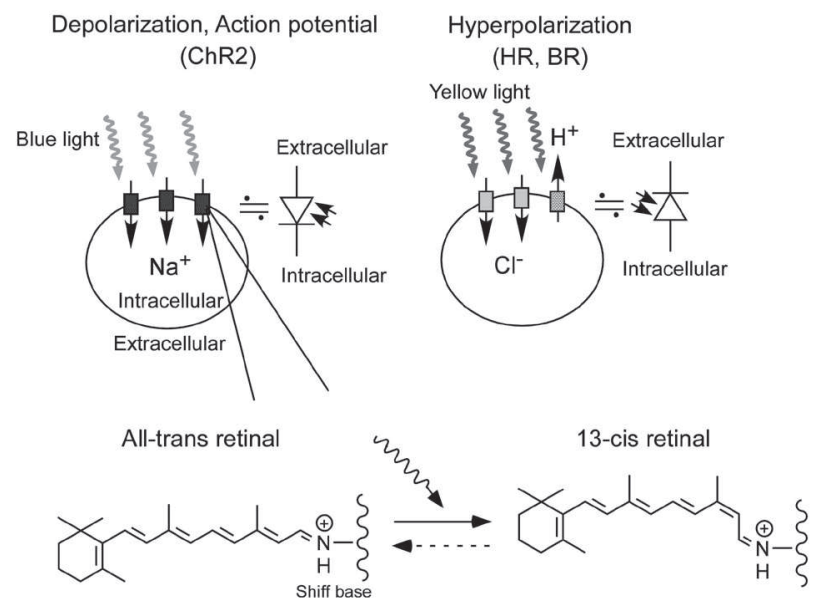

Fig. 7 Optogenetic probes. 

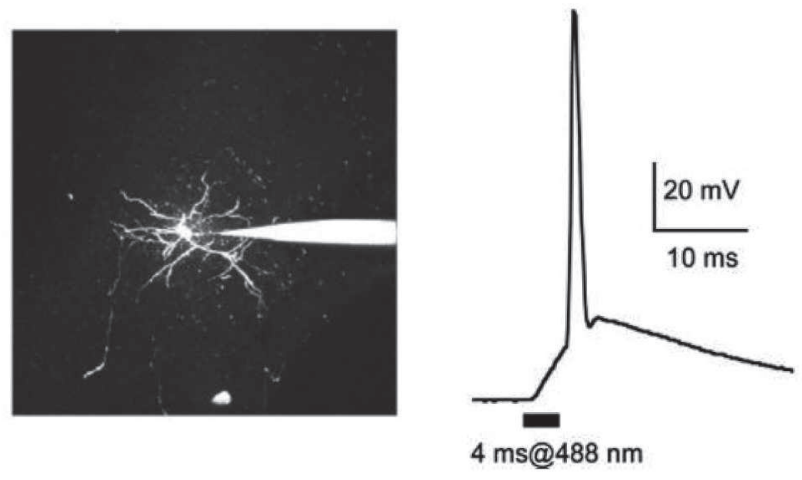

Fig. 8 Action potential induction by $\mathrm{ChR} 2$ photostimulation. Left, two-photon image of a whole-cell recorded neuron in the rat cortical slice preparation. Right, 4-ms photostimulation on the recorded neuron induced an action potential.

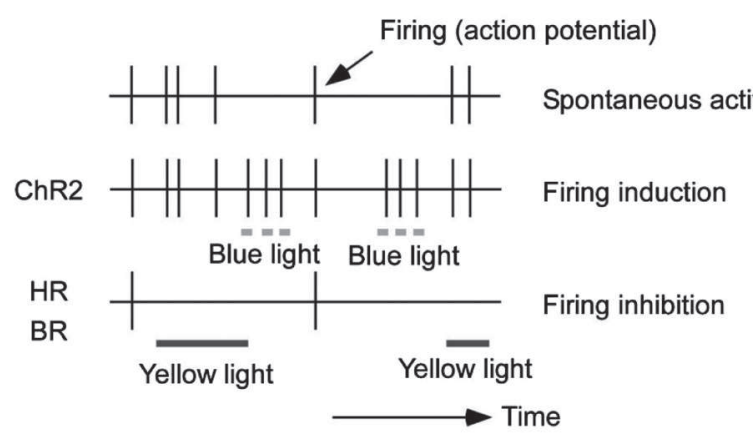

Fig. 9 Photo-manipulation of neuronal activity.

子によってコードされているため, 神経細胞に遺伝子導 入することができ, 標的の細胞で任意の時間パターンで 活動をオンオフ制御することが可能となっている (Fig. 9). このような遺伝学的, 光学的方法を組み合わ せて生体組織の特異的細胞タイプにおける機能獲得, 機 能欠損を操作する分野をオプトジェネティクス (Optogenetics, 光遺伝学) と呼ふ226). 覚醒動物における 光刺激方法としては, 顕微鏡下の頭部固定状態において はレーザー走査照射や全視野照射が可能である。自由行 動下では小型LEDの頭蓋骨への接着，または目的の部位 へ光ファイバを挿入して脳深部を刺激するなど様々な方 法が現在開発されており, 例えばマウスの四肢運動を操 作することができる27,28).この光操作法によって, 複雑 に入り組んだ構造体である神経系に扔いて特異的な回路 機能をリアルタイムに抽出することが可能となった(詳 細や応用例は山中氏の稿を参照のこと)。青色光刺激の 前後での細胞活動を2光子カルシウムイメージングで計 測することで, 覚醒動物の行動中での細胞活動制御・行 動制御とその時の多細胞活動の変化の因果関係を明らか にすることも原理的には可能である。

\section{8. まとめ}

このようにレーザー技術, 光学デバイス技術, 画像処 理技術，そして分子生物学，遺伝子工学の発展によっ て, 多数の神経細胞活動を様々な行動中で計測すること が可能となってきた，これは人工知能や機械学習など
と, 実際の脳の情報処理, 学習機構の相違や同一性を回 路レベルで議論できるようになってきたことを意味して いる，神経科学と情報科学の真の融合が生体イメージン グ分野においても始まりつつあり, 神経疾患も脳回路の 情報処理異常として定式化することも夢ではないかもし れない．この融合に不可欠なものがレーザー計測技術の 発展である。より長波長側 $(\sim 1300 \mathrm{~nm})$ で強度の高いパ ルスレーザーの開発(例えばスペクトラフィジックス社 のInSight $\left.{ }^{\mathrm{TM}}\right)$ はより梁部の脳神経活動の計測をもたらす だろう。レーザー走查法に関わるAODなどの光学素子 の応用や高感度光検出器の開発によって, より高速な3 次元走査が可能となれば, 数千, 数万の神経細胞の活動 時系列データを得ることができる。これに光操作法を加 えることで任意の外乱時の神経細胞活動の時系列変化を 捉えることができるはずである. 生物学者, 医学者, レーザー物理学者, 情報科学者の交流が進むことによっ て，さらなる革新的な研究が生まれることを期待した い.

謝 辞

図の作成には研究室の杉山朋美さんのご協力をいた だきました。感謝申し上げます。

\section{参考文献}

1) E. S. Boyden, F. Zhang, E. Bamberg, G. Nagel, and K. Deisseroth: Nature Neurosci. 8 (2005) 1263.

2) C. Stosiek, O. Garaschuk, K. Holthoff, and A. Konnerth: Proc. Natl. Acad. Sci. U.S.A. 100 (2003) 7319.

3) K. Ohki, S. Chung, Y. H. Ch'ng, P. Kara, and R. C. Reid: Nature 433 (2005) 597.

4) A. Miyawaki, J. Llopis, R. Heim, J. M. McCaffery, J. A. Adams, M. Ikura, and R. Y. Tsien: Nature 388 (1997) 882.

5) J. Nakai, M. Ohkura, and K. Imoto: Nature Biotechnol. 19 (2001) 137.

6) L. Tian, S. A. Hires, T. Mao, D. Huber, M. E. Chiappe, S. H. Chalasani, L. Petreanu, J. Akerboom, S. A. McKinney, E. R. Schreiter, et al.: Nature Methods 6 (2009) 875.

7) T. Komiyama, T. R. Sato, D. H. O'Connor, Y. X. Zhang, D. Huber, B. M. Hooks, M. Gabitto, and K. Svoboda: Nature 464 (2010) 1182.

8) D. Huber, D. A. Gutnisky, S. Peron, D. H. O'Connor, J. S. Wiegert, L. Tian, T. G. Oertner, L. L. Looger, and K. Svoboda: Nature 484 (2012) 473.

9) D. A. Dombeck, A. N. Khabbaz, F. Collman, T. L. Adelman, and D. W. Tank: Neuron 56 (2007) 43.

10) D. A. Dombeck, C. D. Harvey, L. Tian, L. L. Looger, and D. W. Tank: Nature Neurosci. 13 (2010) 1433.

11) C. D. Harvey, P. Coen, and D. W. Tank: Nature 484 (2012) 62.

12) F. Helmchen, M. S. Fee, D. W. Tank, and W. Denk: Neuron 31 (2001) 903.

13) B. F. Grewe and F. Helmchen: Curr. Opin. Neurobiol. 19 (2009) 520.

14) F. Helmchen, D. W. Tank, and W. Denk: Appl. Opt. 41 (2002) 2930.

15) W. Gobel, A. Nimmerjahn, and F. Helmchen: Opt. Lett. 29 (2004) 1285.

16) C. J. Engelbrecht, R. S. Johnston, E. J. Seibel, and F. Helmchen: Opt. Express 16 (2008) 5556.

17) Y. Otsu, V. Bormuth, J. Wong, B. Mathieu, G. P. Dugue, A. Felz, and S. Dieudonne: J. Neurosci. Methods 173 (2008) 259.

18) W. Gobel, B. M. Kampa, and F. Helmchen: Nature Methods 4 (2007) 73. 
19) G. D. Reddy, K. Kelleher, R. Fink, and P. Saggau: Nature Neurosci. 11 (2008) 713.

20) D. S. Greenberg and J. N. Kerr: J. Neurosci. Methods 176 (2009) 1.

21) P. Thevenaz, U. E. Ruttimann, and M. Unser: IEEE Trans. Image Process 7 (1998) 27.

22）松崎 政紀：化学と生物 50 (2012) 406.

23) G. Nagel, T. Szellas, W. Huhn, S. Kateriya, N. Adeishvili, P. Berthold, D. Ollig, P. Hegemann, and E. Bamberg: Proc. Natl. Acad. Sci. U.S.A. 100 (2003) 13940.

24) F. Zhang, L. P. Wang, M. Brauner, J. F. Liewald, K. Kay, N. Watzke, P. G. Wood, E. Bamberg, G. Nagel, A. Gottschalk, et al.:
Nature 446 (2007) 633.

25) B. Y. Chow, X. Han, A. S. Dobry, X. F. Qian, A. S. Chuong, M. J. Li, M. A. Henninger, G. M. Belfort, Y. X. Lin, P. E. Monahan, et al.: Nature 463 (2010) 98.

26) F. Zhang, J. Vierock, O. Yizhar, L. E. Fenno, S. Tsunoda, A. Kianianmomeni, M. Prigge, A. Berndt, J. Cushman, J. Polle, et al.: Cell 147 (2011) 1446.

27) V. Gradinaru, K. R. Thompson, F. Zhang, M. Mogri, K. Kay, M. B. Schneider, and K. Deisseroth: J. Neurosci. 27 (2007) 14231.

28) R. Hira, N. Honkura, J. Noguchi, Y. Maruyama, G. J. Augustine, H. Kasai, and M. Matsuzaki: J. Neurosci. Methods 179 (2009) 258.
チャネルロドプシン2(Channelrhodopsin-2)

チャネルロドプシン2(ChR2) は, 緑藻クラミドモナス が持つ色素タンパク質で古細菌型ロドプシンとして分類 される. 膜タンパク質部分に結合したレチナールに青色 の光子が吸収されるとレチナールの構造が変化し，それ がタンパク質の構造変化を引き起こし陽イオンが膜内外 を透過する.ChR2はクラミドモナスの走光性に関与す
ると考えられている．ChR2などの光吸収によって活性 化されるタンパク質をコードする遺伝子を神経細胞など に導入し，発現したタンパク質を光照射することで細胞 活動を制御する研究分野は光遺伝学 (オプトジェネティ クス)と呼ばれ，この方法論はNature Methods誌のMethod of the Year 2010に選ばれている.

(松崎 政紀) 